\title{
The Technologies of Total Domination
}

\section{Maria Los1}

\begin{abstract}
Could revised concepts of Panopticon and bio-power shed some new light on the unique technologies of totalitarian power? This article explores the key mechanisms of total domination constructed as an ideal type. It treats Stalinist Russia and Nazi Germany as paragons of modern totalitarianism that is characterized by the explicit use of an obligatory, comprehensive, 'scientific' ideology as a political tool of domination. The issues addressed include freedom; the state, law and terror; relations of truth; the self (and the other), and biopower. Specific strategies of surveillance, dissolution of the self and obliteration of the "social" are highlighted to enable recognition of possible re-emergence of totalitarian practices in the current, technologically and politically transformed global universe.
\end{abstract}

\section{Introduction}

"If someone should tell you your shadow sees you, sees you all the time, would you understand?" Eugene Zamiatin, 1924 (1952: 82).

"Call them soldiers, call them monks, call them machines: so they were but happy ones, I should not care” Jeremy Bentham, 1787 (1995:31).

\section{Panoptic on: The Archetype of Total Surveillance}

“[L]a matrice du panoptique, c'est un camp de travail russe réalisé par un ingénieur anglais. Le Goulag, déjà...” Michelle Perrot: 1977:188.

An architectural form, invented in the 1780s by Samuel Bentham, Brigadier General in the Russian Service, to improve industrial discipline in Russia, the Panopticon was subsequently elaborated as a versatile instrument of government by his jurist-philosopher brother, Jeremy Bentham. Its essence consisted in 'the centrality of the inspector's situation, combined with the well-known and most effectual contrivances for seeing without being seen" (Bentham, 1995 [1787]: 43; emphasis in the original). While Jeremy Bentham envisaged it as a circular building

${ }^{1}$ Department of Criminology, University of Ottawa, Canada mailto:marialos@uottawa.ca 
and offered detailed explanations of all possible aspects of his ultimate "inspection house," the contemporary reader may visualize it in terms of an arrangement common in our prisons: a closed circuit television system monitored by a handful of functionaries. Prisoners know they are watched all the time, even if the eyes of the monitors are not continuously fixed on them.

In Bentham's conception, Panopticon aims at a total, centralized surveillance of individuals who are constantly aware of being visible. Visibility replaces force as a tool of control. It is more economical, it reduces the need for physical contact between the supervisors and supervised, and any contact that is required is visible to the Inspector in the central tower (Bentham, 1995; Perrot, 1977). Bentham lauds his design as a "new mode of obtaining power of mind over mind, in a quantity hitherto without example: and that, to a degree equally without example, secured... against abuse" (1995: 31).

Panopticon principle is simultaneously totalizing and atomizing. This may be one of the most important features of the technology of power it enables. Anyone familiar with Bentham's Panopticon Letters is also likely to recognize many of his cherished principles in Orwell's literary rendition of the totalitarian society. As noted by Michelle Perrot and various other authors, the same principles may also be found at the root of the real life totalitarian projects.

\section{The Panoptical Power and liberal practic es of freedom}

For Bentham, Panopticon was a great invention that would allow rationalizing all forms of human organization based on utilitarian principles. It would also open unprecedented possibilities of systematic collection of information and thus development of various branches of practical knowledge. To facilitate orderly and beneficial organization of labour and surveillance, separate categories of people - the poor, the ill, convicts, workers - could be dressed in different uniforms, confined to different spaces or tasks and, if necessary, marked physically through such forms of body branding as tattoo and disfigurement (Perrot, 1977:184). These methods of regulation would be permitted as long as they do not reduce the individual's ability to do productive work. Through Panopticon, such aspects of human existence as diet, lighting, hygiene, sleep and contact with others could be strictly regulated, maximizing the benefit for the society and individuals involved (Bentham, 1995). Bentham made it clear that in addition to being an architectural form, his Panopticon was meant to be viewed as an abstract "figure of political technology... polyvalent in its application" (Foucault, 1979a: 205; Bentham, 1995; see also Foucault, 1977, 1979a, 1980, 1988).

Explaining the nature of development of the carceral/panoptical power in the XIXth century, Michel Foucault (1979a) talks about carceral continuum, whereby penitentiary techniques became defused and spread outwards into complex networks of disciplinary training. Since functions such as punishing, curing and educating were not essentially different and all relied on mechanisms of normalization, this carceral continuum worked to 'naturalize' legal power to punish and to 'legalize' the technical power to discipline. The Panoptical power, produced through relations of discipline, showed its greatest intensity in the bodies of the subjects, individualized through these new relations and the new branches of knowledge centred on the 
human body (1979a: 208). This represents a gradual move towards a generalized surveillance based on a growing penetration of the whole social body by mechanisms of discipline that are increasingly capable of fulfilling productive and normalizing rather than simply neutralizing functions.

In Foucault's interpretation, in addition to its role in constituting the self as a site of power, Panopticon also enables and epitomizes the invisible, continual, capillary nature of modern power, its anonymity and diffusion. "It's a machine in which everyone is caught" - he said in an interview - "it becomes a machinery that no one owns... If the machine were such that someone could stand outside it and assume sole responsibility for managing it, power would be identified with that one man and we would be back with a monarchical type of power" (Foucault, 1980: 156, 158).

The uninterrupted, omnipresent, calculated gaze (le regard), hierarchy, continuous and functional reward-punishment system, all of these elements contribute to and enforce a particular type of order. While it is an "artificial order" that is "laid down by a law, a programme, a set of regulations," it is also "defined by natural and observable processes: the duration of apprenticeship, the time taken to perform an exercise, the level of aptitude" (1979a: 179). Mechanisms of differentiation, hierarchization, homogenization and exclusion work in the service of productive (multi)disciplinary relations that combine and integrate juridical and natural references into seemingly seamless system. This enormously complex and diverse machinery enables individuals to partake in the forms of power it produces. The new visibility of individual subjects prompts them to work discipline unto themselves and turns them into the calculable persons (Foucault, 1979a: 193). Foucault described processes through which disciplinary practices, interwoven with practices of sovereignty, became absorbed into an emerging framework of modern government of the population, involving security and bio-political practices concerned with the defence, administration and optimization of life/human resources, based on ever expanding knowledge of the population (Foucault, 1991).

The continuous grip of disciplinary power in contemporary Western societies can of course be disputed, especially in view of political shift away from the welfare state, new patterns of liberalization, globalization and mobility and development of new control technologies (see, for example: Yar, 2003). While Foucault never attempted an inquiry into genealogy of freedom as a technique of government, there is no doubt that practices of freedom, especially in their liberal and, more recently, neoliberal versions, have long been part of Western technologies of governing. Several authors have offered interesting insights on the subject (see, for example, Burchell, 1991; Gordon, 1991; Lacombe, 1993; Rose, 1999; Dean, 1999). Exploring the genealogy of liberal government, Dean points to the importance of studying how 'the advanced liberal government' operates through practices of liberty, 'i.e. practices concerned with structuring, shaping, predicting and making calculable the operation of our freedom, and of working off and through diagrams of free subjects constituted by forms of governmental and political reasoning" (Dean, 1999: 165-6). Nikolas Rose (1999), in his inquiry into the changing modes of governing through freedom, shows how freedom has become a structuring theme of Western government. He looks at freedom as "a mode of organizing and regulation ... a certain way of administering a population that depends upon the capacities of free individuals" (Rose, 
1999: 64). The implicit logic of these technologies is widely different from that of mechanical, totalizing dominance of a perfect Panopticon.

\section{My Objectives}

The continuing debate on disciplinary and bio- power technologies in modern democracies notwithstanding, it may be enlightening to explore their potential or actual place in nondemocratic political systems. What is different about the organized practices and related rationalities, through which people in totalitarian countries are governed, govern themselves and govern others? Are practices of bio-power and their relationship to knowledge and security apparatus significantly different under such regime? Do panoptical technologies of power and techniques of surveillance work differently within different political contexts? Do they constitute, facilitate, extend or modify the core features of a particular regime of power? Could a revised concept of Panopticism shed some new light on key mechanisms of the totalitarian power? Let us not forget that just as Foucault and others saw prison as integral part of modern transformation of power so did Hannah Arendt - some years earlier - saw concentration camp as the key to understanding the mechanisms of the Stalinist and Nazi totalitarian regimes.

The objections from many critics notwithstanding, I am following here Hannah Arendt's decision to treat the Stalinist Russia and Nazi Germany as paragons of modern institutionalized practice of total domination known as scientific totalitarianism. ${ }^{2}$ This historical category includes also such states as Mao's China, Cuba and North Korea. While they share many characteristics with religious ideocracies, there are also significant differences between those forms of totalitarianism that are based on religion and those that claim to be based on a scientific ideology, exemplified by Nazism or Communism. I treat modern totalitarian regimes as distinct from authoritarian (despotic, dictatorial) regimes, such as Franco's Spain and a number of Latin American military regimes. The centralized apparatus of control in an authoritarian state is designed to secure the continuation of the regime through exclusion of people from political participation and suppression of opposition. It does not aspire to achieve a comprehensive political penetration and subjugation of all spheres of social activity (see: Piekalkiewicz and Penn, 1995 for an interesting discussion on ideocracies and how they differ from autocracies; see also Lefort, 1986:79).

Based on her analysis of Stalinist Russia and Nazi Germany, Arendt gave us a brilliant account of what they had in common and abundantly demonstrated that "totalitarian rule confront[ed] us with a totally different kind of government" (1958: 461). I see my task in more modest terms. In this essay I attempt to revisit the issue of totalitarianism with a fresh conceptual toolbox, a broad spectrum of absorbed literature, ${ }^{3}$ my own research and my experience of living for many years in the orbit of both Soviet totalitarianism and haunting memories of Nazi occupation. I am focusing

\footnotetext{
2 I am not going to review here the arguments against subsuming 'brown' and 'red' regimes under one rubric. They have not convinced me. Needless to say, the totalitarian paradigm does not deny the existence of important differences or the need to study them.

${ }^{3}$ This literature includes countless memoirs and first hand accounts by survivors of these regimes, which are not included in my list of References.
} 
on main mechanisms of totalitarian domination constructed as an ideal type, and not on their historical details, complexities, dynamics and inconsistencies. The empirical and literary examples I invoke are meant to serve only as illustrations and means of elucidation of my theses. The main issues I address in this article are as follows: freedom; the state, law and terror; relations of truth; the self (and the other) and bio-power (bio-pouvoir).

\section{The Totalitarian Power}

\section{Freedom}

Unlike the modern liberal technologies of power that require a sense of freedom in the subjects, the totalitarian power depends on the total opposition to the very notion of individual freedom and its positive connotations. Total domination can only be realized in the name of and with the aid of a total ideology, an ideology that is monistic, comprehensive, global and timeless. This ideology's vital importance does not lie in the numbers of those who actually believe in it - they may be quite insignificant - but in the peculiar technology of domination it makes possible. The subordination of life and death to this kind of ideology creates and justifies an imperative of suppression of any hint of alternative interpretation, open-ended possibilities, local voices or doubt.

Acknowledgement of freedom - in any of its manifestations, such as choice, initiative, spontaneity, privacy - refutes this ideology and its ideal of total domination, which is predicated on the spectacle of unity, dissolution of the self and automatic submission to authority. This distinguishes totalitarian rule from autocratic dictatorship, which strives to restrict practices of political freedom by often very drastic means, but does not aim at suppressing ideas of choice and agency in some other, depoliticized areas. Moreover, it does not rely on ideological mobilization of the population (Arendt, 1958:405; Piekalkiewicz and Penn, 1995:16). The notion of freedom is the key premise of liberal ideology. In liberal societies, the assumption of individual freedom is part of the rationale that drives the market and public life, and the division between private and public spheres is expected to provide a space of relative respite from the gaze.

As Arendt points out, one of the powerful totalitarian mechanisms of negation of freedom is "consistent arbitrariness." While the authoritarian state makes its opponents the primary target for persecution, in a perfect totalitarian state the very meaning of opposition is negated. Arendt explains: "Theoretically, the choice of opposition remains in totalitarian regimes too; but ... freedom [to oppose] is almost invalidated if committing a voluntary act only assures a "punishment" that everyone else may have to bear anyway.... [T] he opponent of the regime in Russia, suffering the same fate as millions of people who are chosen for concentration camps to make up certain quotas, only relieves the police of the burden of arbitrary choice. The innocent and the guilty are equally undesirable" (1958: 433). This is integral part of the terror mechanism that must back up any claim of total domination. Under such conditions, martyrdom becomes impossible (451). Moreover - as I elaborated elsewhere (Los, 1988:142-3) - people who cling to their survival strategies do not want to be reminded about the degradation and mendacity of their existence and are, therefore, inclined to believe that those who try to protest are either crazy or self-destructive rather than moral or free. 
Among the many mechanisms of subverting the very meaning of freedom is the spectacle of selfcriticism, widely practiced in communist countries. Evoked by torture, terror and psychological manipulation, self-criticism turns a critic of the system into its enforcer. In his book on propaganda, Jacques Ellul commented:

That the enemy of the regime ... can be made to declare, while he is still the enemy, that this regime was right, that his opposition was criminal and that his condemnation is just - that is the ultimate result of totalitarian propaganda. The enemy (while still remaining the enemy, and because he is the enemy) is converted into a supporter of the regime (1973:11; emphasis in the original).

The ideological repudiation of the individual freedom to resist is combined with the image of almost divine omnipotence of the rulers, especially the Leader. There is no limit to what they may and can do. The spectacular glory of mass mobilization, the terror, the concentration camps, the desolation and mindless indoctrination, all serve to convince people that they live in a realm where the usual limits on what is possible do not apply. This implies a total defeat of common sense and of natural human tendency to connect, understand, rationalize and predict. The resultant feelings of heightened vulnerability may enhance sense of dependency on the Leader, who represents power amidst powerlessness and a fixed centre amidst the chaos.

The thesis that the negation of possibility - or even meaning - of freedom is one of the constitutive features of totalitarianism does not preclude a meta-analysis of linkages between liberalism and totalitarianism. It may, for example, be fruitful to look at totalitarianism as an extreme form of validation and absolutization of those repressive practices that under liberal regime are constructed as necessary guarantees of freedom (see, e.g. Agamben, 1998; Dean, 1999). It may also be instructive to analyze totalitarianism as an attempt to resolve paradoxes inherent in democracy (Lefort, 1986). Given, however, the limited space and particular focus of this article, these are not subjects I am going to explore here.

\section{The state, law and terror}

"constant motion prevents the inroads of germs and other organisms" Mao Tse Tung, 1945 (1976:260).

For totalitarian leaders, the seizure and maintenance of political power are not sufficient. Their ultimate goal of total domination must have the transcendental qualities that only an earthly utopia can offer. This calls for total, lasting mass mobilization that requires a compulsory vision of a glorious future, a clear statement of the objective Laws of History (or Nature) and an identified source of their only correct, scientific interpretation and criteria of compliance. This kind of a closed, self-referential system has an in-built ability to turn signs of evident failure into the imperative for intensified indoctrination, radicalization and perseverance.

A global, historical mission cannot be accomplished in one community or one country; nevertheless they may provide a suitable site for both the movement's headquarters and social laboratory. Totalitarian movements - as Arendt points out - "reckon victories and defeats in 
terms of centuries and millennia ... and the global interests always overrule the local interests of their own territory" (1958: 411). This global claim is inherent in the totalitarian ideology. If local regimes

"do not pursue global rule as their ultimate goal, they are only too likely to lose whatever power they have already sized. Even a single individual can be absolutely and reliably dominated only under global totalitarian conditions" (392, emphasis added).

The totalitarian state is no ordinary state. It must accommodate both the dynamics of a global movement and the logic of a locally bound experiment. Neither concern for the interests of the local population nor the stabilization of the local regime can take priority over the global mission of total domination. Arendt refers to "the perpetual-motion mania of totalitarian movements" (306). She describes various mechanisms - such as a "regular violent turnover of the whole gigantic administrative machine" (413) in Stalin's Russia - which serve to sustain instability and prevent a confrontation of the fictitious world of the movement with stubborn reality of society. (For comparisons of murderous purges of Nazi and Soviet officials, see Johnson, 1983: 296302 and Taylor, 1993: 61).

In so far as Foucault's generalized Panoptical-disciplinary mechanism secures stable predictability of social arrangements and a good fit between the formation of the individual and realistic opportunities for advancement and stabilization, it has no place in the totalitarian movement-state. Accordingly, any references to normal standards, practical learning sequences and natural/temporal limits to human capabilities contradict the totalitarian assumption of tabula rasa and infinite malleability of human beings. A discourse of life goals, career planning, qualifications and recognized credentials is alien and antithetical to the totalitarian project. For the same reason, a stable, formal, legal framework cannot be reconciled with a movement organized around the Iron Law of History - or a similar formula - as the supreme source of authority. It is up to the Leader to interpret this Law in the correct way in any particular historical moment, which places the Leader above the law, although ostensibly not above the ideology (see Piekalkiewicz and Penn, 1995:70 for an elaboration of this idea).

The word of the Fürer becomes the law (Agamben, 1998). And the law is undistinguishable from reality, thus contracting the space for individual moral responsibility. To accomplish this, the Leader has to establish a personal, near-religious bond with the people (or at least its external, visible manifestations), founded on awe, adoration and fear rather than ideological commitment. "Only men of destiny, with tasks preordained by history (if not the ancient Nordic gods themselves) can credibly demand that their followers surrender to him the space in which personal moral decisions are taken" (Le Bor and Boyes, 2001: 18).

The doctrine of Leader's infallibility is based on the assumption of the possibility of correct interpretation of the predictable and "essentially reliable forces of history or nature" (Arendt: 349). Whether the Leader's will is dressed as ideology or ideology is adopted as the Leader's will, they need each other to make this total claim work. As Hastings indicates, Hitler's nationalism and anti-Semitism were purely emotional and "it was left to Himmler, Rosenburg, 
Heydrich and their colleagues to create the fantastic edifice of scientific racial theory which they employed to justify the Final Solution" (1968:9).

For total domination to succeed, the old concept of law has to be eradicated. "The first essential step on the road to total domination is to kill the juridical person in man" - observes Arendt (1958: 447; for analyses of the totalitarian law, see Podgorecki, 1993; Pogorecki and Olgiati, (eds.), 1996). Arendt points to a peculiar form of seeming resistance to this process, when concentration camp prisoners identify themselves with special categories imposed on them by the camp system "as though they represented a last authentic remnant of their juridical person" (450). The Soviet and Nazi concentration camps, run by secret services, played a special role in the process of dejuridification.

The Nazis had fashioned their camps after the Leninist-Stalinist prototype, and Soviets, in turn, learned eagerly from their experience (see, e.g., Johnson, 1983:304). Arendt recognized concentration camps as the "central institutions of totalitarian organizational power" (438; see also, e.g., Krausnick and Broszat, 1970; Solzenitsyn, 1974, 1976; Foucault, 1980; Herling, 1985). Arguably, neither the Soviet Union nor Nazi Germany can be understood or would be possible without this ingenious invention. Based on his chronological reconstruction of the history of German concentration camps (from 1933 to 1945), Broszat concludes that they were "an important criterion as to whether Nazi absolutism, once it was firmly entrenched [in mid 1930s], would content itself with the authoritarian transformation of the State, or whether it would strive further to absorb and dissolve its legal and constitutional framework" (Krausnick and Broszat, 1970: 144). The camps were both separate from the society and deeply imprinted in it, simultaneously denied and replicated in the general population. The forced labour in the camps was paralleled by the compulsory, assigned labour outside it; the perversion of science, methodical crashing of the body and soul, dehumanization of death were all practiced in this parallel, complementary fashion.

To pursue total, monistic domination, the ruling structure cannot be itself monolithic and coherent, yet it must generate a belief in a menacing deeper unity, hidden underneath and perpetuated behind the scenes. The ambiguity of the power arrangement between the movement (the Party) and the administration (the State) is deliberate and inherent in the project of total domination and its globalization. While the former rules with no formal legal basis, the latter is a façade trapped over a legal frame. The lack of clear hierarchy, the vagueness, shapelessness and duplication of functions and services prevents establishment of a stable government that might lose revolutionary zeal and start to perceive the masses not as an expandable matter but a population to govern. The masses need to acquire a Kafkaesque sense that the true power structure does not lie in the visible maze of offices, but is deeply hidden and profoundly secret.

Hans Mommsen's description of the National Socialist regime's perplexing structures illustrates this tendency:

The system of overlapping at hoc competencies negated any kind of rational division of labor and functions ... The existing bureaucratic institutions were gradually emptied of substance... Instead, new "secondary" bureaucracies ... 
emerged in the twilight zone between public administration and party apparatus.... [This] was rooted in a perception of politics exclusively aiming at propagandistic integration and mobilization, capable of mediating diverging interests only within the purview of an ultimate goal conceived chiliastically (Mommsen, 1981: 160, 161, 162).

All this produces a sense of conspiracy and the type of mentality that "sees every conceivable action as an instrument for something entirely different" (Arendt, 1958: 409; Podgorecki, 1991:168-70). Nothing can be taken at its face value. There are, therefore, no valid criteria for pragmatic action or even for positioning oneself within the maze. This unique type of Panopticon serves to confuse and immobilize the masses without giving them practical programs for stability and advancement. Common sense references and natural expectations quickly prove useless when mass experiments are carried out to prove that a menial worker can exchange places with a surgeon, the industry can be built by melting pots and pans collected from the country's kitchens, mass arrests of engineers serve technical progress and mass famine promotes prosperity.

Within the opaque power maze, Supreme Leader's role has some affinity to Bentham's vision of the hidden but seemingly all-knowing Inspector. What counts is social awareness of his watchful presence behind the scenes - his apparent, God-like omnipresence. The Inspector is not a fiction, he must really exist, but to maintain the fiction of his divine qualities he should only sporadically reveal himself in person. His power "over the prisoners derives from his invisibility, or more precisely, his "invisible amnipresence" (Božovic, 1995:9). The effectiveness of the panoptical surveillance hinges on an image, a fiction, a state of mind. There is, however, an added mechanism at work in a totalitarian Panopticon, which is possible because of the prevailing conspiracy consciousness. It allows people to simultaneously view the Leader as an omnipotent, all-seeing god (or monster) and place blame for many hated policies and atrocities on his underlings, who are believed to have somehow, escaped his gaze.

The executive power is concentrated in the hands of the political secret police whose quasiinvisible presence is felt everywhere. Yet secret services themselves have to be multiplied and set against each other for mutual supervision, surveillance and vigilance. Beyond the initial phase, when they focus on crashing the actual opposition, their main functions centre on spreading terror and compiling knowledge. Total domination cannot be achieved without terror and the particular knowledge it produces and requires. It starts as a tool for suppression of strife, but evolves into a complex power technology calculated to achieve such long-term goals as interiorization of fear, breaking of social bonds, destruction of predictability and creation of new categories of objective enemies.

\section{Relations of truth}

"...it is a unique history which is inaugurated with totalitarianism... the attempt to close the social space in on itself from the imaginary centre of its institution, to make being and appearance coincide here and now" (Claude Lefort, 1986: 220). 
For Foucault, relations of truth and the power-knowledge nexus are key to understanding power and its discursive, relational nature. A distinctive feature of totalitarian ideology is its explicitly dogmatic, basically non-discursive character - its brazen claim to a total, logically coherent, scientifically proven Truth. Of course, in the actual totalitarian practice, changing political interpretations, or doctrines, are common, but they are not integrated with the earlier ones through a consistent thread of rationality. The new doctrine is simply declared to be objectively true as if the preceding one never existed. No one is supposed to notice the glaring contradictions, confusing shifts in terminology, clashing prophesies, arbitrary revamping of the past and tinkering with the vision of the glorious future. While people's lives depend on these slogans (or, rather, on the political intentions hidden behind them), no one is really supposed to make any sense of them. With time, people develop a certain instinct, which helps them to search for nebulous signs of unspecified danger or reassurance and to find clues as to what truth is currently expected of them: is black still white or has it changed to blue or green? (For a classic literary llustration, see: Orwell, 1954:169-71). This kind of truth is not produced by application of any rational criteria. It is meant to overcome the need for them.

The oddity of totalitarian truth relations lies in the deliberate and systematic fabrication and promotion of falsehood as a sign of the Party's omnipotence. These lies do not have to be credible, consistent or "naturalized" through believable, natural or testable references. The Party's superior power is validated when people actually say what it wants them to say. Breaking subjects' mental/moral integrity is the first step in their subjugation. In the long run, this strategy of ruling strives to erase the very need for distinguishing between truth and lie and discredit any former epistemological, moral and linguistic standards attached to them.

The underlying assumption seems to be that through intensive mass training - involving indoctrination sessions, marching, chanting slogans, will-breaking ceremonies, self-denunciation rituals, arbitrary sanctions and terror - a combination of fear, opportunism, stupidity and exhaustion will produce the desired indifference to truth and falsehood. When people no longer trust their senses, the make-believe reality becomes certified. ("I tell you, Winston, that reality is not external. Reality exists in the human mind, and nowhere else. Not in the individual mind, which can make mistakes, and in any case soon perishes: only in the mind of the Party, which is collective and immortal" (Orwell, 1954: 200). A former Soviet penal logging camp prisoner recalls: "We worked under all frost conditions, even at well under $-40 \mathrm{C}$. At the watchpost at the camp gates, however, there was a sign that read, 'There is no frost in the taiga!"” (Shifrin, 1982: 181).

The entire institutional regime machinery is geared to prevention and sanitation of any forms of knowledge that may emerge spontaneously or through professional efforts. All sectors and agencies of the totalitarian regime, such as the statistical office, education, health, penal system, industrial complex, army and police, are generating enormous amount of information selectively tailored to meet specific political expectation, propaganda effects, censorship criteria and economic quota. Endless forms are filled with streams of data contrived in anticipation of the centre's wishes. A paper reality is created that takes life of its own. It is geared to negation of problems and fabrication of success. It also serves to create in subjects a surreal sense of being 
oppressed by make-believe reality. The constant tension between the (Weberian) logic of bureaucracy and the (il)logic of the ideologically-driven party results in de-rationalization of bureaucracy and bureaucratization of ideology and, therefore, routinization and normalization of fiction. The bureaucratized ideology substitutes a fiction for reality and reproduces it in ever more inclusive domains.

Amidst this huge machinery, bent on producing diverse types of deliberately manipulated knowledge, secret police services are practically the only agency expected to maintain a firm grip on reality. While various university departments are being closed or decimated, secret services hire or secure collaboration of experts to assist them in their diagnostic tasks. They have to be careful, however, not to pass to the Leader findings he does not want to hear. They continuously collect and process information about individuals, families, communities, organizations, agencies, industries and all other social and economic entities. This heavily guarded secret knowledge which is only selectively shared with the top political leadership - is conditioned and structured according to the logic and mission of the security apparatus. It consists of two main types of knowledge: the operational surveillance knowledge (contained in individual/group/site files) and aggregated, diagnostic knowledge about various spheres and sectors of society. The latter may and occasionally does inform policy-making/implementation processes.

The concentration camp is at the core of the secret knowledge-production processes and their rationality is measured by the progress in mastering the logistics of mass transportation, slave labour and extermination machinery ostensibly in the service of ideological purity. Both Soviet and German authorities kept detailed records of prisoners, the categories they fell into as well as other particulars, such as their movements, family ties, believes or creed, tasks and fate. Both regimes experimented and perfected their techniques. They used either hardened violent criminals or prisoner-functionaries selected from among the political prisoners to control the general inmate population; they multiplied camp categories; revised selection, segregation and distribution techniques; synchronized the intake of new prisoners with fluctuation in demand for slave labour, and constantly searched for more efficient ways of killing and of eliminating corpses. They conducted pseudo-scientific experiments on the captive populations in order to develop and test new techniques of surveillance, brain-washing, genetic engineering or chemical and biological warfare.

Given that the postulated objects of totalitarian rule are different than objects/subjects of liberal governance, the kinds of knowledge and disciplinary power-knowledge nexus required also differ considerably. The unity of power and knowledge is achieved through the modern totalitarian regime's assertion of scientific nature of its monistic ideology. The scientific totalitarianism of the twentieth century has created a political non-discourse that excludes differentiation and possibility of discursive presence of 'the other.' Instead, a voiceless other is constructed and announced in an essentially non-discursive manner as an 'objective enemy,' an enemy whose destruction is necessary to vindicate ideology. Chairman Mao's definition of the people may serve as an illustration:

[T]he classes, strata and social groups which favour, support and work for the cause of socialist construction all come within the category of the people, while 
the social forces and groups which resist the socialist construction are all enemies of the people (Mao Tse Tung, 1976: 46).

The un-German elements, kulaks, Jews or social parasites were enemies because they were not "people" and not because of what they did or thought. This assumption in itself precludes the construction of credible, shared rules of rationality as ever growing layers of population are defined out from the terrain of the "social."

\section{The Self (and the Other)}

According to Bentham, the ingenuity of his Inspection House lies in its double effect, whereby the inmates appear "to the keeper, as a multitude, though not, a crowd; [while] to themselves they are solitary and sequestered individuals" (1995: 50; emphasis in the original). Social atomization precludes rebellion. Totalitarian projects strive to achieve social atomization through forced collectivization and total surveillance of the society at large. The role of mass movements is not to bring people together as individuals but rather as insignificant particles, assembled together to assume appearance of masses following the leader. All eyes are supposed to be turned first of all towards the Leader (or his image) and only then towards those around them in order to make sure that they do not deviate from the path. The strength of the masses rests on the feeling of insignificance by individuals. The totalitarian technology of the self must strive to purge the self and replace it with indivisible "we." In Zamiatin's novel, We, which became a blueprint for Orwell's Nineteen Eighty-Four, the narrator comments:

To assume that I may have any "rights" as far as the State is concerned is like assuming that an ounce may equilibrate a ton in a scale! ... [T]he natural road from nothingness to greatness is to forget that one is a gram and to feel that one is one millionth of a ton! (1952 [1924]: 109).

In a totalitarian Panopticon, judgement is based on the individual's interconnected appearance (with whom one may be connected) and on the secret police reports. This arrangement fosters self/other control, guilt by association (collective responsibility) and dissolution of the self. It totalizes through atomization, both of which are essentially objectifying. It works to erase the possibility of individual resistance. Through a simple device known as "guilt by association," family, friends and acquaintances of the accused are automatically considered suspect or contaminated. To save their skin, they are prone to be transformed into the doomed person's enemies by volunteering information, denouncing and berating the accused (see, e.g., Arendt, 1958: 322).

The 'scientifically' derived totalitarian regulation both programs the hollowing of the self and hails this process as imperative for the movement's success. While totalitarianism may still be analyzed as a moral regulation movement (Hunt, 1997: 282), the morality of its objects is constructed in a way that is supposed to prevent their subjectification or active involvement in ethical work on their own selves. In short, they are meant to lose their identity as moral subjects and become morally inseparable from the movement. 
In his comments on the Greco-Roman civilization, Foucault draws attention to the theme of care of the self that permeated moral reflection of the time. To willingly relate to oneself, know oneself, care for oneself, improve oneself, master one's appetites, were all imperatives around which ethics as a conscious practice of freedom revolved (Foucault, 1997:285). It can be argued that there is some, even if tenuous, affinity between these moral techniques of antiquity and the surreptitious cultivation of the self under the totalitarian regime. While the former acquired meaning through the contrast to slavery, the latter represents a form of resistance against massive political technologies of eradication of the self. This is evident in the extraordinary importance of the true, tested, self-nourishing friendship, the constant practicing of self control, separation of public acting and private living (if any privacy still remains) and conscious efforts to know (while also denying or rationalizing) the limits of one's courage, humanity or even sheer physical fortitude.

Yet, moral strategies to salvage (and nourish) the self are inevitably combined with and often compromised by strategies of survival that require betrayal of the ethical self. In extreme situations of total domination, a radical detachment from one's self may be the best available strategy. Some concentration camp survivors testify that only by separating themselves from their selves could they distance themselves from the dehumanization visited upon them. They became strangers to themselves, sometimes to the point of identifying with the oppressor (Grygier, 1954).

On a different level, the memoirs of Tadeusz Grygier, Polish lawyer-psychologist, survivor of the Soviet gulag, offer remarkable insights into his predicament. A man well tutored and experienced in powers of self-care/knowledge, he found them invaluable in achieving a state of selfdetachment and a wilful conversion from a victim into researcher. "Instead of seeing myself as a prisoner destined to die in the camp, I redefined myself as a lucky scientist who had penetrated the forbidden zone of the gulags..., and who was able to observe the effects of oppression on other prisoners, myself and our guards" (Grygier, 2002:76). He morally neutralized the brutal regime and learned to deal with arising issues by using his understanding of the working of the system, its representatives and its victims, thereby testing his hypotheses in practice.

Cultivating and displaying powers of observation is not a strategy of survival commonly adopted in totalitarian societies, however. There is always danger of seeing too much or appearing to be seeing too much. The surveillance principle typical for these regimes may be viewed as an enhanced version of the classical Panopticon. In this form of surveillance, each member of the society is also aware of being turned into a potential policeman for others, a secret eye of the system. Since the totalitarian secret security complex recruits and cultivates a web of secret informers, who are obliged to spy and report on their family, friends, neighbours, co-workers, strangers, etc., everyone must be suspected of being one. ${ }^{4}$ It is prudent to do so. Consequently, not only are people constantly and acutely aware that they are watched by dispersed, unidentified secret surveillance agents, but they are also conscious that others view them as

\footnotetext{
4 This was more pronounced in communist countries than in Nazi Germany, where the police system tended to rely on voluntary denunciation rather than registered informers. The result was similar, however, as the Gestapo was flooded with denunciations volunteered by ordinary Germans (LeBor and Boyes, 2001).
} 
potential agents of secret police. In addition to becoming agents of their own subjection, they are thus turned into objects used as tools in policing others. This happens without their participation, simply by virtue of being in the orbit of totalitarian control (see Los, 2002, Los and Zybertowicz, 2000).

Within such double-edged Panoptical arrangement, 'inmates' have no way of verifying who is a secret agent and have no way of preventing others from suspecting them of being spies. As a result, people try to reduce not just their visibility but also their appearance of being, seeing and knowing. This mechanism reinforces one of the key premises and effects of the totalitarian project - the erosion of citizenship, trust and basic social solidarity. The terror-induced fear is transformed into a normalized fear, which leads to elaborate conformity-projecting strategies. Their effect is the formation of psychological and mental straightjacket in the form of a set of taboos and magical lines one should never cross.

In the absence of clear rules, institutional guarantees or a rationality-based political culture, each individual almost instinctively marks for him or herself the taboo areas to avoid. The world of ordinary people becomes structured through a series of such taboos involving subjects, spaces, behaviours, gestures, words and persons. According to its original meaning, taboo is 'a prohibition backed up by a magical spell. It designates things and persons possessing powers that constitute dangers of which one must be wary.... Anybody who breaks a taboo is bound to suffer some harm' (Wiedemann, 1993:43). This characterises well the almost magical quality power takes on in totalitarian societies. People do not know what exactly will happen if they appear to act as autonomous persons, but they know that harmful consequences will inevitably befall them. Even when no visible, direct repercussions occur, they visualise a new black mark in their secret file and wonder what curse this may later bring upon them or their children (see Los, 2002).

The principles at the core of these strategies of ruling are neither positive disciplinary normalisation (with its implicit imposition of norm) nor juridical codification (with its explicit stress on right). The taboo mentality produces a negative, yet magical conditioning. There is no obvious guiding rationality or truth to lend sense or authority to this exercise. It is up to the people themselves to construct a semblance of rationality within their day-to-day existence. Powerful surveillance and management processes that continuously turn the private into public underscore fragility of this project.

\section{Bio-power (mana gement of life)}

"After 1933, National Socialism was publicized as 'the biological will of the people,' and as 'political biology”' (Helmut Krausnick, 1970:31).

"... they cut off people's heads for decades and at last saw the birth of a new type of headless people" (Vladimir Bukovsky, 1978:87).

Many authors have contributed to our knowledge of the processes of re-constitution of the "King's subjects" into a society that could be known, whose diverse problems and needs could 
be addressed by specialized institutions and qualified personnel and whose members' aspirations and quality of life became inseparably linked to the exercise of (liberal) government.

Foucault's concept of bio-power (or pastoral power) refers to the administration of conditions and processes of life. It concerns those mechanisms of power and knowledge production that focus on life itself, by problematizing it, investing in it, shaping it, enhancing, maximizing, and so forth (Foucault, 1979b). Various areas of human life, such as those constructed as hygiene, sex, diet and reproduction, fall within the domain of bio-politics. Its dark side lies in its potential for disallowing or disqualifying life within the context of care or population enhancement. This may range from programs of sterilization of mentally ill to decisions about rational use of scarce medical resources to regulation concerning discontinuation of life support or euthanasia.

Development of bio-power and bio-politics has been intertwined with the advancement of human sciences, such as medicine and psychology. Human sciences tend to construct society through a focus on individual human beings, who have unique needs and are neither expandable nor inter-changeable. In contrast, scientific totalitarianism relies on a concept of society derived from organic or technical sciences where the parts have no meaning other than being inane components of the whole. The whole has no obligations towards its parts, while the parts have to fulfil their humble roles for the machine or a body to work. Unlike liberal ideology, totalitarianism does not confer any rights (even the right to life) on individuals just because they were born human. Mass movements, which aim at saving humanity, the race or the people, cannot afford to be slowed down by weak or obstructive elements. Hitler made this principle very clear in his 1944 speech to a group of officer cadets:

Nature is always teaching us...that she is governed by the principle of selection: that victory is to the strong and that the weak must go to the wall. She teaches us that what may seem cruel to us...is nevertheless often essential if a higher way of life is to be attained. Nature...knows nothing of the notion of humanitarianism which signifies that the weak must at all costs be surrounded and preserved even at the expense of the strong (quoted in Krausnick, 1970:29).

Lenin, who saw morality as subordinated to the objective interests of the class struggle of the proletariat, announced in an essay published in 1918 a program of "purging the Russian land of all kinds of harmful insects" (quoted in Solzhenitsyn, 1974:27). This started a frantic hunt for "parasites" that outlasted him for many decades (see Los, 1988: 89-98). Stalin explained brutal purges within his own Party by likening it to a living organism: "Like every organism, it undergoes a process of metabolism: the old and atworn moves out; the new and growing lives and develops" (quoted in Amis, 2002:167). Chairman Mao spoke against allowing "political dust and germs to dirty our clean faces or eat into our healthy organisms," and he likened the Party to a surgeon who saves the patient by removing his appendix (Mao Tse Tung, 1976: 265, 262). The rituals of mass blood-letting over which these leaders presided were part of grand schemes of social prophylaxis and purification, necessary for production of a better form of life.

Purging of the social body did not have to aim precisely at diseased elements, being instead performed as a cleansing ritual, whereby society expels a set amount of matter to revitalize itself. 
When Stalin liquidated numerous categories of enemies of the people, the victims were often chosen according to the pre-set quota. For instance, in the campaign against kulaks, each village had to name families to be purged even if there were no rich peasant families residing in the area, and in the 1927 campaign against "industrial wreckers," each factory was obliged to single out some engineers as saboteurs (Solzhenitsyn, 1974:43). Similarly, during the Chinese land reform campaign in the 1950s, at least one million landlords were executed based on certain quota for each district (Taylor, 1993:4). There is, however, a tension between organic and inorganic representations of the society. This is well explained by Lefort:

[T] he two images do not fully merge; the image of the body is altered when it comes into contact with that of the machine. The latter contradicts the logic of identification; the communist 'us' is itself dissolved... making the social appear at the boundaries of the inorganic... Once the old organic constitution disappears, the death instinct is unleashed into the closed, uniform, imaginary space of totalitarianism (1986: 301, 306).

The type of knowledge that appears to thrive under a totalitarian regime is a knowledge that rationalizes death as a resource, facilitates formation of the self-less objects and suppresses alternative knowledges. Both Nazi and Stalinist regimes developed complex technologies of killing as a form of population management. They involved intricate mechanisms of selection, regulation, division of labour, economization, ritualization, de-individualization and normalization. These were rituals of imprinting complicity in general population, designed to foster moral anaesthesia and re-definition of human beings as nothing more than transitory clusters of recyclable matter, disposable parts of the machine, or a pest.

The process of turning people into "human material" and its macabre relationship to human sciences is well described in a memoir by Dr Nyiszli, a Jewish prisoner of Auschwitz, who saved his life by becoming Dr. Mendele's assistant:

When the convoys arrived, soldiers scouted the ranks lined up before the box cars, hunting for twins and dwarfs... Dr. Mendele wanted to solve the problem of the multiplication of the race by studying the human material - or rather, the twin material (Nyiszli, 1973: 52, 80).

The process of killing - carried out largely by prisoner kommandos - was permeated by medical symbols and knowledge. The deadly gas was delivered by Red Cross cars and introduced into the gas chamber by the Deputy Health Officer (p.48).

Then a new phase of the exploitation and utilization of Jewish bodies took place... Hair was also a precious material, due to the fact that it expands and contracts uniformly, no matter what the humidity of the air. Human hair was often used in delayed action bombs, where its particular qualities made it highly useful for detonating purposes. So they shaved the dead. ...[T]he dead were next sent to the "tooth-pulling" kommando... All members of the kommando were fine stomatologists and dental surgeons (50; emphasis added). 
In the Gulag, severe Russian climate made possible a symbolic use of the bodies through their continuous, frozen display in the camps and surrounding areas. Solzhenitsyn and other survivors of the Soviet Gulag described how Soviet camp authorities coped with the body-disposal tasks in wintertime when the ground was frozen. "[E]very morning the orderlies hauled the corpses to the gatehouse, stacking them there" (Solzhenitsyn, 1976:112). "The corpses were left unburied. In May they used to decompose - and at that point the "goners" who had survived until then were summoned to cover them up" (115). The climate was also employed in the task of killing, whereby many hungry, exhausted prisoners simply froze to death or were placed in locked death carriages for failing to fulfil their work quota and simply left in them for a day to freeze. The bodies were then tossed out and left in the open (114).

Totalitarian practices render the distinction between life and death increasingly blurred, thus necessitating development of new technologies for surveillance and administration of populations of the "living dead." Concentration camps, politically induced famine, pseudoscientific experiments, psychiatric punishment - these are all examples of this peculiar condition, in which people are not dead but no longer live. The aim is to annihilate the uniqueness of the human person (Arendt, 1958: 453). Society of Pavlov's dogs, who can be conditioned on the most basic, biological level, represents both a triumph and a defeat of the totalitarian disciplinary regime. When human disciplines serve to erase the line between life and death, their familiar human subject is turned into an incomprehensible dehumanized body, whose domination is no longer ideologically meaningful.

Human sciences were deeply engaged in dehumanization of the population as a whole as they were both applied to this end and stimulated by new needs and new data generated through these practices. From propaganda and brain washing to elaboration of new types of mental disease to reproductive regulation programs, the key role of human sciences in producing totalitarian power is evident. Their individualizing potential is blocked, when they are made subservient to a total "scientific ideology." As a result, the historical totalitarian states often relied on quite archaic modes of population management, based on spatializing, observing and immobilizing (terms used by Foucault to describe Bentham's architectural Panopticon, 1980: 160). There is a striking resemblance between the Soviet comprehensive regulation and restriction of population movement (to avoid contamination and spread of dangerous ideas) and Foucault's description of the plague control regulations at the end of the seventeenth century:

[A] strict spatial partitioning: the closing of the town and its outlying districts, a prohibition to leave the town on pain of death, the killing of all stray animals; the division of the town into distinct quarters, each governed by an intendant. Each street is placed under the authority of a syndic, who keeps it under surveillance... If it is absolutely necessary to leave the house, it will be done... avoiding any meeting (1979: 195).

Such Soviet policies as prohibition to leave the country, internal passports, restricted residence permits, work permits linked to residence permits, closed cities, the use of penalty of banishment, duty to work and collective housing, exemplify the utilization of this, rather rudimentary Panoptical arrangement. It relies on "discipline as a blockade" and is generally 
associated with "the enclosed institutions, established at the edges of society, turned inwards towards negative functions: arresting evil, breaking communications, suspending time" (Foucault, 1979a: 209). The emulation of this type of institutional discipline in the general population management subordinates all other forms of bio-politics to the same negative logic. The emergence of the collective and the brigade as key organizing principles of totalitarian, surveillance-oriented bio-politics illustrates this tendency.

In his Gulag Archipelago, Solzhenitsyn shows the evolution of the Soviet camps, established in 1918. In the following excerpt, he comments on the early, experimental stage of their development:

Not often is it possible to arrange such mass labor projects as in the gravel pit near Yaroslavl; there hundreds of prisoners are clumped together in a small area visible to the naked eyes of the supervisors, and hardly has any one of them stopped moving than he is immediately conspicuous. These are ideal conditions. ... How, then, is it to be managed in other cases? Much thought was applied. And the brigade was invented (1976:142).

The brigade represents a modified Panopticon principle. The brigadier is a prisoner who takes on the role of a temporary overseer and executioner, while sharing the doomed destiny of his or her fellow prisoners:

"Slave driving the prisoners with club and ration, the brigadier has to cope with the brigade in the absence of the higher-ups..." (Solzhenitsyn, 1976: 143). "[I]f the logging brigade failed to fulfil the day's norm ..., the brigadier went into the punishment block too. And if you don't want to go to the punishment block, then drive your brigade members to their death. Bow down to the stronger!" (145).

A survivor of the Auschwitz concentration camp, sociologist Anna Pawelczynska describes a Nazi version of the brigade system:

Authority over the work crews as a whole was exercised by a prisoner - the Lagerkapo - and a large staff of subordinate Kapos with their own staffs of underlings responsible for the individual work crews. This group of functionaries was responsible for the organization of work and its results, the dividing up and formation of work crews, escorting the crews to the work site, supervising the performance of work, accompanying back to the camp those who survived the day and seeing that those who did not survive ... were also delivered back to the camp. In practice the forming of work crews often meant beating the prisoners and driving them like cattle (1979: 47).

According to the official Bolshevik language, the brigade was introduced to provide its members with "psychological enrichment" and "heightened sense of dignity" (Solzhenitsyn, 1976: 143). The same cryptic code applied to the "collective labour" introduced in the society at large, where 
brigade system became the primary form of organization of labour and enforcement of work discipline. Far from being limited to the economic sphere, the collective became an organizing principle throughout the society. It was a strategy of absorption of the private by the public in order to enable generalized surveillance and disciplinary re-education of the society. Developed by Anton Makarenko and other Soviet specialists in education and psychology, the collective mechanism was based on mutual surveillance, collective correction (admonition) and selfrevelation (Kharkhordin, 1999). Work, family and neighbourhood collectives discussed everyday problems and personal lives of members, applied to them norms of socialist ideology and enforced current work and family related policies. They were regulated by the state and formed "the substance of official public life in Soviet Russia" (Zdravomyslova and Voronkov, 2002: 66). The collective housing policy initiated in Soviet cities in the early 1920s further reinforced the pervasiveness of social surveillance and atomization through collectivization. It targeted spaces hitherto considered private. Individual families were no longer allowed to be sole occupants of their apartments, but were instead forced to share them with other families. Parental influence was undermined by child rearing policies that taught young children to become "dependent on the collective for guidance and direction, ... learn from it to exercise selfdiscipline, and ... subordinate [their] interests to those of the collective" (Finckenauer, 1995: 4).

While Nazi policies did not have the methodical collectivist orientation of the Stalin's policies, they too aimed to weaken parents' role in upbringing of children, despite the official pro-family rhetoric. To achieve this, they relied on the Hitler Youth organization, a network of boarding schools for racially pure children ("with a strong flavor of army cadet college") and the Adolf Hitler school for the future elite, where "[s]tep by step, mothers and fathers were banished from the lives of their children and familial loyalty was transferred to the teacher, to the school and to the Fürer" (LeBor and Boyes, 2001: 53). To provide a new framework to people's lives and eradicate religious influence, both the Nazis and the Soviets introduced "a new calendar, new occasions of tribal celebration and new cults" (117). There were new holidays, anniversaries related to the new regime or its Leader, new marriage and funeral ceremonies as well as elaborate initiation ceremonies for the young. ("Ten-year-olds were formally induced into Nazi youth organizations, fourteen-year-olds publicly 'confirmed' their commitment to the Hitler Youth," 118).

The collectivist management of life is consistent with the overall political technology of totalitarianism, which is predicated on the dissolution of the self and civil society. It aims at abolishing both continuity and choice in social relations, replacing them with artificial, non-optional social environment for atomized, mutually controlling individuals.

\section{Conclusion}

"The Gulag is not a question to be posed for any and every country. It has to be posed for every socialist country, insofar as none of these since 1917 has managed to function without a more-or-less developed Gulag system" (Michel Foucault, 1980: 137). 
The twentieth century's totalitarian experience has had a deep impact on intellectuals and their canons of thought. Grand theories, grand narratives as well as concepts of totality, necessity, truth and essence have become symbolic of a road to precipice. Arguably, this post-traumatic intellectual shift has both enriched us, by opening new vista, and impoverished us, by invalidating other paths of inquiry. Moreover, the fear of totalistic thoughts might have blinded many leading intellectuals to the need to pay systematic attention to the totalistic practices - both past and present - and to explore in depth the totalitarian party-state as a distinct formation. This has led both to "banalization of the totalitarian," whereby the label is applied loosely and irresponsibly (Le Goff, 2002) and to efforts to discredit totalitarian state classification of the Stalinist regime as a cold war fabrication not deserving scholarly attention (exemplified by Hoecherl-Alden et al., 1995).

Michel Foucault suggested a useful distinction between the Gulag institution and the Gulag question. The former can be studied as any other political technology by looking at its history, transformations, functions etc. He insisted, however, on the "specificity of the Gulag question against all theoretical reductionisms ..., against all historicist reductionisms ... [and all] universalizing dissolutions into the general form of interment" (1980: 137). While he recognized the importance and uniqueness of the Gulag question, he did not elaborate on it.

The real, historical totalitarian regimes I focused on had convoluted histories, were highly corrupt, made sometimes concessions to public opinion, built industries and opened opportunities for advancement for selected classes or strata. They were, however, essentially, dehumanizing regimes bent on comprehensive, negative control of human beings. I used the designation "totalitarian" as different from "authoritarian" to stress the importance totalitarian regimes attach to explicit, obligatory ideology as a political tool of domination. Consequently, they base their power on mobilization of the masses, all-embracing politization and repudiation of the private sphere, various techniques of mass brain washing, cognitive and physical terror, and coercive political inclusion. Authoritarian regimes use political exclusion and focus their repression on actual or imagined opposition to their domination without aspiring to mobilize or politicize the masses.

Bentham's assessment of his Panopticon probably overestimated the power of the gaze to penetrate and reform people. They may watch their steps and control their appearance without revealing their inner thoughts to the external gaze. Their self-control may be superficial, their synchronization with the movements of others in the workhouse or the army purely mechanical, their commitment half-hearted. Similarly, it is easy to overestimate the thought control exercised by totalitarian regimes. In both cases, however, there are real mechanisms at work that affect the target population profoundly and systematically. I have elaborated in this article several mechanisms of totalitarian domination conceived as an ideal type.

Total ideology does not have to be believed in; its role is to enable a mode of political management calculated to produce total domination or at least an impression of total domination conjured through terror or mystification. ("Goebbels did manage to convince most Germans that he was exerting control over the minds of most other Germans," Allen, 1981: 255) A political non-discourse is created that excludes differentiation and possibility of discursive presence of 
'the other.' While total power depends on social atomization, its "legitimation" is demonstrated through a spectacle of unity. This requires steady production of enemies and triggers massive processes of de-normalization and dehumanization when large numbers of ordinary people are turned into 'objective enemies' (non-people). Additionally, the spectacle of self-criticism makes the infinite power of ideology (and, consequently, of the Leader) visible to anyone by magically turning the enemy of the regime into its enforcer. Totalitarian power is secret and conspiratorial but not anonymous. The Leader stands apart from the society and personifies omnipower, while secret services represent institutionalized production of repression.

The uniqueness of totalitarian "truth relations" lies in the fact that deliberate and systematic certification of falsehood functions as a proof of the Leader/Party's omnipotence. By making people repeat zealously obvious lies, the regime breaks their mental integrity and confirms its positive power over their minds. With time this strategy produces atrophy of the need to distinguish between the truth and lie and destroys former epistemological, moral and linguistic rules that made such a distinction possible. Assertion of scientific nature of the official ideology and subjugation of all disciplines to its criteria of reality brings palpable singularity to the power/knowledge relationship.

Instead of Bentham's physical separation of individuals, the totalitarian regime uses collectivization and comprehensive mutual surveillance as a strategy of social atomization. This enhanced version of Panopticism goes beyond the internalization of the all-seeing eye and the habit of self-policing. Each member of society is also aware of being potentially viewed by others as a secret eye of the system.

Totalitarian ideology views society as an organic or mechanical whole, whose parts have no individual meaning. This limits the individualizing potential of human sciences within totalitarian bio-politics. They are engaged in and transformed by projects of social prophylaxis and purification that involve mass blood-letting rituals and rationalization of death as a resource. Routine population management relies on essentially negative methods of blocking exit, spatializing, observing and immobilizing as well as on collectivist technologies aimed at production of self-less, disposable, interchangeable individuals.

Given the totalitarian practice of obliteration of what Foucault described as 'the social' and its replacement with a fictitious society of the ideological movement, it is very difficult to analyze these societies without sounding ideological. In this article I looked at the totalitarian regimes of the XXth century, exemplified by the Stalinist Russia and Nazi Germany. The mechanisms I described had been conditioned by the technology and political realities of the time. With rapidly changing surveillance technologies and accelerating globalization, these practices may re-emerge and be mediated in a different fashion. It may still be useful, however, to have some understanding of the basic rules that made possible totalitarian domination of the past century.

\section{References}

Agamben, G. (1998) Homo Sacer. Sovereign Power and Bare Life. Stanford: Stanford University Press. 
Allen, W.S. (1981) Totalitarianism: the Concept and the Reality. In E.A. Menze (ed.) Totalitarianism Reconsidered. Port Washington, NY and London: Kennikat Press, 97-106.

Amis (2002) Koba the Dread: Laughter and the Thirty Million. Toronto: Alfred A. Knopf Canada.

Arendt, H. (1958) The Origins of Totalitarianism. Cleveland and New York: Meridian Books.

Bentham, J. 1995 [1787] The Panopticon Writings. London/New York: Verso.

Božovic, M. (1995) Introduction: “An Utterly Dark Spot.” In Bentham, J. The Panopticon Writings (ed. Božovic). London/New York: Verso, 1-27.

Bukovsky, V. (1978) To Build a Castle. My Life as a Dissenter. London: Andre Deutsch.

Burchell, G. (1991) Peculiar Interests: Civil Society and Governing "The System of Natural Liberty.” In G. Burchell, C. Gordon and P. Miller (eds.) The Foucault Effect: Studies in Governmentality. Chicago: University of Chicago Press, 119-50

Dean, M. (1999) Governmentality: Power and Rule in Modern Society. London: Sage.

Ellul, J. (1973) Propaganda: The Formation of Men's Attitudes. New York: Vintage Books.

Finckenauer, J.O. (1995) Russian Youth. New Brunswick (USA) and London: Transaction.

Foucault, M. (1977) L'oeil du pouvoir. In M. Perrot (ed.) Le Panoptique. Paris: Pierre Belfond, 7-31.

Foucault, M. (1979a) Discipline and Punish. New York: Vintage Books.

Foucault, M. (1979b) The History of Sexuality, Vol. I. London: Allen Lane.

Foucault, M. (1980) Power/Knowledge (ed. by C. Gordon). New York: Pantheon Books.

Foucault, M. (1988) Technologies of the Self. In L.H. Martin, H. Gutman and P.H. Hutton (eds.) Technologies of the Self. London: Tavistock, 16-49.

Foucault, M. (1997) Ethics, Subjectivity and Truth. Edited by P. Rabinow. New York: The New Press.

Gordon, C. (1991) Governmental Rationality: An Introduction. In G. Burchell, C. Gordon and P. Miller (eds.) The Foucault Effect: Studies in Governmentality. Chicago: University of Chicago Press, 1-51

Grygier, T. (1954) Oppression: A Study in Social and Criminal Psychology. London: Routledge and Kegan Paul; New York: Grove Press.

Grygier, T. (2002) Exile: The Road to Knowledge. Toronto: The Canadian Polish Research Institute.

Herling, G. (1985) Un Monde à part. Paris: Denoel.

Hoecherl-Alden, G, T. Jung, and J. Redmann (1993) The Myth of Red Equals Brown: The Origins of Totalitarianism Theory. In J. Hermand, (ed.) Postmodern Pluralism and Concepts of Totality. New York: Peter Lang, 1-25.

Hunt, A. (1997) Moral Regulation and Making-up the New Person: Putting Gramsci to Work, Theoretical Criminology, 1(3): 275-301.

Johnson, P. (1983) A History of the Modern World. From 1917 to the 1980s. London: Weidenfelt and Nicolson. 
Kharkhordin, O. (1999) The Collective and the Individual in Russia: A Study of Practices. Berkeley: University of California Press.

Krausnick, H. and M. Broszat (1970) Anatomy of the SS State. London: Granada.

Lacombe, D. (1996) Reforming Foucault: a Critique of the Social Control Thesis, British Journal of Sociology, 47(2): 332-52.

LeBor, A. and R. Boyes (2001) Seduced by Hitler. The Choices of a Nation and the Ethics of Survival. Naperville, Ill.: Sourcebooks.

Lefort, C. (1986) The Political Forms of Modern Society. Cambridge, Mas.: MIT Press.

Le Goff, J.-P. (2002) La Démocratie post-totalitaire. Paris: Editions la Découverte.

Los, M. (1988) Communist Ideology, Law and Crime. London: Macmillan Press; New York: St. Martin’s Press.

Los, M. (2002) Post-communist Fear of Crime and the Commercialization of Security, Theoretical Criminology, 6(2): 165-88.

Los, M. and A. Zybertowicz (2000) Privatizing the Police State. The Case of Poland (Foreword by G.T. Marx). London: Macmillan Press; New York: St. Martin's Press.

Mao Tsetung (1976) Quotations From Chairman Mao Tsetung. Peking: Foreign Languages Press.

Mommsen, H. (1981) The Concept of Totalitarian Dictatorship versus the Comparative Theory of Fascism: The Case of National Socialism. In E.A. Menze, (ed.) Totalitarianism Reconsidered. Port Washington, NY/ London: Kennikat Press, 146-166.

Nyiszli, M. (1973) Auschwitz. A Doctor's Eye-witness Account. Frogmore, AL: Mayflower Books.

Orwell, G. (1954) Nineteen Eighty-Four. Harmondsworth: Penguin Books.

Pawelczynska, A. (1979) Values and Violence in Auschwitz: A Sociological Analysis. Berkeley: University of California Press.

Perrot, M. (1977) L’Inspecteur Bentham. In Bentham, J., Le Panoptique (Ed. by M. Perrot). Paris: Pierre Belfond, 169-219.

Piekalkiewicz, J. and Penn, A.W. (1995) Politics of Ideocracy. Albany: State University of New York Press.

Podgorecki, A. (1991) A Sociological Theory of Law, Milano: Dott. .A. Giuffre Editore.

Podgorecki, A. (1993) Social Oppression. Westport and London.: Greenwood Press

Podgorecki, A. and V. Olgiati (eds.) (1996) Totalitarian and Post-Totalitarian Law. Aldershot: Dartmouth.

Rose, N. (1999) Powers of Freedom. Cambridge: Cambridge University Press.

Shifrin, A. (1982) The First Guidebook to Prisons and Concentration Camps of the Soviet Union. Toronto, New York, London, Sydney: Bantam Books.

Solzhenitsyn, A. (1974) The Gulag Archipelago, Vol. 1.Great Britain: Collins-Fontana.

Solzhenitsyn, A. (1976) The Gulag Archipelago, Vol. 1.Great Britain: Collins-Fontana. 
Taylor, J. (1993) The Rise and Fall of Totalitarianism in the Twentieth Century. New York, NY: Paragon House

Wiedemann, P.M. (1993) Taboo, Sin, Risk: Changes in the Social Perception of Hazards. In B. Ruck (ed.) Risk as a Construct: Perceptions of Risk Perception, Munich: Knesebeck, 41-63.

Yar, M. (2003) Panoptic Power and the Pathologization of Vision: Critical Reflections on the Foucauldian Thesis, Surveillance and Society, 1(3): 254-71.

http://www.surveillance-and-society.org/articles1(3)/pathologisation.pdf

Zamiatin, E. (1952 [1924]) We. New York: E.P. Dutton.

Zdravomyslova, E. and V. Voronkov (2002) The Informal Public in Soviet Society: Double Morality at Work, Social Research, 69(1): 49-70. 